Article

\title{
The Role of Networks in Improving International Performance and Competitiveness: Perspective View of Open Innovation
}

\author{
Junghyun Yoon ${ }^{1}$, Sanghyun Sung ${ }^{2, *(1)}$ and Dongwoo Ryu ${ }^{1, *}$ \\ 1 School of Business, Yeungnam University, Gyeongsan 38541, Korea; jyoon071121@ynu.ac.kr \\ 2 POSTECH Entrepreneurship Center, Pohang University of Science and Technology, Pohang 37673, Korea \\ * Correspondence: flyparis@postech.ac.kr (S.S.); rdw999@ynu.ac.kr (D.R.); Tel.: +82-10-8553-9838 (S.S.); \\ +82-10-5393-1753 (D.R.)
}

Received: 31 December 2019; Accepted: 5 February 2020; Published: 10 February 2020

\begin{abstract}
With perspective view of open innovation, this study examines how international networks form and evolve and the empirical relationships among antecedents of international network embeddedness, international performance, and sustainable competitiveness. Data from 356 small and medium-sized exporters (SMEs) in manufacturing or technology industries in South Korea are analyzed by structural equation modeling. It assumes that international network embeddedness plays a mediating role in the relationship between internationalization and related variables. This analysis indicates that information management and proximity significantly affect international performance, while cultural differences do not, and that international network embeddedness mediates relationships between information management and international performance, and proximity and international performance. The results imply that greater international network embeddedness increases SMEs' international performance-information management and proximity play a pivotal role in embedding international networks and improving international performance. SMEs must establish and intensify international networks to improve international performance and seek to overcome limitations by developing international networks with the goal of entering international markets. Nevertheless, there is relatively little research on international network formation and embeddedness, especially for SMEs. This study determines network formation principles, determinants of international networks, and roles of international network embeddedness in relationships between the determinants and international performance. Notably, this study verifies a comprehensive model of international networks.
\end{abstract}

Keywords: perspective view of open innovation; International network embeddedness; information management; cultural difference; proximity; international performance; small and medium-sized exporters

\section{Introduction}

In spite of the fact that small and medium-sized exporters (SMEs) play essential roles in economic growth, relatively few studies have been devoted to them [1-3]. Essentially, SMEs have turned to international markets to overcome the difficulty of maintaining and expanding their domestic market share [4]. These companies especially seek niche strategies, and their success might depend on their ability to enter international markets [5]. SMEs use networks to cope with their inherent limitations, such as lack of resources [6-9]. Thus, SMEs must leverage other firms' abilities and resources $[10,11]$ to enter international markets. Consequently, SMEs are interested in establishing and/or enhancing their international networks to carry out successful internationalization [12-14] or accelerate international marketing activities [3]. Nevertheless, previous studies [15] have not 
considered why international networks form or explored the determinants of networks; that is, it is very important for entrepreneurs who want to expand their operations into global market to understand the determinants of internationalization. In addition, except for a few studies [16], most previous studies do not explain the network formation principle using a theoretical mechanism. Therefore, this study aims to understand the network formation principle, and hence explain international network issues based on said principle, as well as identify the influence of international networks on international competitiveness (an outcome of internationalization) based on SMEs in the manufacturing or technology industries. More specifically, this study comprehensively investigates the empirical relationships among the determinants of international networks, the embeddedness of international networks, the international performance, and the competitiveness by employing structural equation modeling (SEM) based on SMEs rather than the larger organizations commonly emphasized in the traditional internationalization literature [17]. This study identifies antecedents of international network embeddedness based on a comprehensive literature review of network formation principles and examines the role of international network ties or embeddedness on the relationship between the antecedents and the international performance. To contribute to researchers who would like to study internationalization, this study addresses why SMEs would like to create international network, and conceptualizes the role of international network embeddedness in terms of information management, cultural difference, and proximity in improving SMEs' international performance and competitiveness. Moreover, overcoming the above limitations of traditional internationalization studies, this study seeks to help future researchers of internationalization develop studies on this topic by suggesting a comprehensive conceptual model and research direction.

\section{Literature Review and Hypotheses}

\subsection{Network Formation Principles}

Import-export companies use networks as representative tools to achieve internationalization in uncertain business environments that allow cooperation in diverse routes and types to reach strategic goals [18]. Lee [19] argues that prior studies on internationalization of import-export companies focused on network formation to sustain existing relationships or to create new relationships due to the benefits of addressing the inefficiency problems arising from diseconomies of scale and uncertainty. Moreover, informal practices arising from political, economic, social, and cultural issues help to improve strategic flexibility and accumulate social capital more than formal practices [20]. Considering the role of social capital spanning trust, mutual understanding, reciprocity, and reputation in the process of constructing spontaneous cooperation network, this approach has benefits from securing autonomy in the process and a method to achieve common goals [21]. Spontaneous cooperation potentially decreases transaction costs, and it offers opportunities for internationalization [22-25]. This paper aims to identify informal collaboration based on originated networks for export firms' internationalization process and identify various attributes or antecedents that influence network formation. Danese [26] focused on analyzing the service delivery process and the firms' performance in networks, both local and international. There has been little study on how networks are created, evolve, and are sustained over time. Selecting business partners is very important, especially for internationalization, as this process carries a certain level of risk in contracts and cooperation, and firms can minimize the associated information and enforcement costs by using networks to select trustworthy business partners. In other words, through these dense networks and strong ties, organizations can acquire more sustainable competitive advantages than competitors [16].

The reason why SMEs would like to form, and hence evolve, international networks is because they have to employ others' resources for successful internationalization. This can be explained through a resource-based perspective. With their inherent limitations, such as lack of resources, SMEs turn their attention from domestic markets to international ones in order to overcome said limitations. Therefore, they are required to have and hold internal capabilities to penetrate international markets. 
We assume that the research subjects of this study already have these capabilities, considering just physical factors as determinants of international network ties or embeddedness.

\subsection{Determinants of International Network Embeddedness}

The preconditions for and determinants of international networks have relevance to general network mechanisms. That is, by analyzing the existing mechanisms for network formation, this study would like to understand the characteristics of international networks. Generally, the strategic management literature has suggested three primary mechanisms: complementary, positional, and proximity $[15,18,27,28]$. The complementary mechanism is based on complementing a network between two parties, and the positional mechanism is used to obtain valuable information and trust by parties' positions, and the proximity mechanism creates a network based on time and spatial situations. This study uses the proximity mechanism to explain a cooperation network with international partners because it considers information management, cultural differences, and physical proximity as antecedents of an international network. Meanwhile, Gulati [16,29] proposed that "throughout three mechanisms (i.e., reach, richness, and receptivity), network resources create value that individually and collectively shape performance" [16] (p. 211). This suggestion means that amicable and reciprocal relationships with other companies require dense networks and strong ties that emerge through repeated interactions favored by the proximity mechanism. In contrast, sparse networks and weak ties could not provide these advantages in the same context and to the same extent. In light of this, we would like to understand and measure the international networks' reach, richness, and receptivity because the proximity mechanism, especially physical proximity, is closely connected to this suggestion. By this mechanism, an international network should be determined according to the organization's characteristics, such as insufficient resources; hence, a closer geographical and physical proximity may accelerate the formation of international networks [3]. This phenomenon increases opportunities to meet and interact with potential partners, thus creating or strengthening a cooperative relationship [27,30]. Rivera [31] investigated the relationship between physical proximity and network formation in team-based organizations, and showed that organizational members working in the same office or space communicate by email and video calls more frequently than those working elsewhere, and tend to establish a positive network with other members. Fleming [32] found that network ties, or embeddedness, is reinforced in the same area; this also applies to business groups such as the science parks in the UK or Silicon Valley in the US, where networks between companies have dramatically increased [33]. In other words, the smaller the physical distance, the more easily the networks are created [16,34,35]. "Small-world" network studies [36-38] emphasize the role of proximity in improving innovation creativity. Similarly, Goldenberg and Levy [39] confirmed that trade intensity decreases as physical distance increases. Considering these findings, this study assumes that geographical or physical proximity may significantly influence whether SMEs establish a network.

Hypothesis 1 (H1). Physical proximity has a positive (+) effect on international networks.

Abilities to manage information play a crucial role in accelerating internationalization by overcoming the barriers of physical distance [40,41], which were previously not considered as an alternative route for effective communication and network building [42]. Therefore, this study considers an ability to collect and manage useful information regarding successful internationalization as the second main factor in embedding international networks [17,39] because firms must take advantage of information systems in the modern information era to establish an international network [41]. Moon [40] emphasized that information sharing, which helps firms achieve common goals, can be one of the major determinants of international partnerships or networks. Li and Atuahene-Gima [43] suggested efficient information sharing as a possible cooperative strategy based on online networks to penetrate international markets. Networks help exporters acquire more useful information about targeted international markets to mitigate export risks [3]. Based on 346 SMEs, one study showed that 
the capacity to search for and manage export information, particularly information on international markets, significantly influences international performance and networks [44]. In the same vein, Child and Hsieh [45] confirmed that the stronger abilities to collect and manage information organizations have, the stronger network ties can be created. Thus, the ability to manage information is directly correlated with international networks and sustainable competitiveness $[3,12,20]$.

Hypothesis 2 (H2). Information Management has a positive (+) effect on international networks.

Finally, this study proposes cultural difference as another key factor determining international network formation in a global market. Thomas and Mueller [46] argued that, except for some problems arising from business situations, widely varying cultural backgrounds cause many difficulties. If exporters cannot understand and overcome cultural differences, they never form positive international partnerships or networks, because the differences could affect communication negatively [47], by creating bottlenecks in a cooperative network [30,48]. Jo [49] also found that in the early stages of foreign direct investment (FDI), the wider the cultural distance, the higher the adjustment and integration cost to establish an international network. Exporters have difficulty maintaining their contracts compared to manufacturing companies because they do not have enough time to overcome cultural differences. Sharmo and Blomstermo [50] claimed that, in order to establish a fruitful partnership or a cooperative network, organizations must understand cross-cultural issues. This study thus assumes that mutual understanding between different cultures can significantly influence international network formation and embeddedness or ties.

Hypothesis 3 (H3). Cultural difference has a negative (-) effect on international networks.

\subsection{International Network Embeddedness and International Performance}

Some researchers have argued that the network embeddedness (the strength of network ties) is a determining factor for internalization of firms seeking a cooperation network with international partners [13,51]. For instance, Monferrer [5] found empirical support for the effects of a network on international performance or sustainable competiveness by examining new international ventures, thus discovering the direct and indirect mediating effect of a network on differentiation-and cost-based competitive advantage- and confirming that a network is an important factor in improving international performance. In a study of 155 Czech SMEs, Musteen [52] found that an international network plays an important role in accelerating internationalization and improving international performance.

Sepulveda and Gabrielsson [53] analyzed exporters' network development as an internal growth resource in the business-to-business context and revealed a meaningful correlation between resource accumulation and network development, and that network development leads to more opportunities to improve internationalization performance. Findings from a study based on 394 Spanish SMEs demonstrated that SMEs that are able to leverage their knowledge gained by experience on open innovation into a differentiated competitive strategy achieve superior performance in international markets [17]. Similarly, Julien and Ramangalahy [44] noted that the role of international network in the relationship between information management strategy and performance is very significant based on a study of 346 exporters. Additionally, Camison [17] argued that exporting SMEs' international performance coincided with their ability to open up a new market and/or sustain close relationships with business partners in the global market. Investigating empirical relationships between networks among leading edge firms and their performance improvements, Uzzi [18] found that using embedded ties with network partners leads to better organizational performance in global markets. According to Andersson [54], external business embeddedness significantly influences product development and market performance, confirming the strategic importance of external networks in maintaining and strengthening performance and developing competence. 
Several reasons for a positive relationship between network embeddedness and performance are as follows. First, the reduced uncertainty in a cooperation network accelerates internationalization as embeddedness helps overcome the barrier of physical distance $[40,41]$. Second, higher network embeddedness implies the creation of new relationships or transactions [55]. Third, closer relationships enable a better understanding of network partners, and more efficient marketing activities, such as global marketing [56]. Fourth, actors in long-term relationships can have a better understanding and/or knowledge of their counterparts and consequently increase opportunities to improve international performance $[54,57,58]$. Finally, SMEs competing for successful internationalization can play the role of customers or suppliers to other firms in target global markets, and be a role model to others. Organizations with international networks or connections and experience would facilitate internationalization for other firms in the same network, achieving a win-win effect $[4,59,60]$. This study thus proposes the following three hypotheses based on this discussion of international networks and suggests that the relationships between determinants of the network and international performance can be mediated by international network embeddedness.

Hypothesis 4 (H4). The relationship between proximity and international performance can be mediated by international networks.

Hypothesis 5 (H5). The relationship between information management and international performance can be mediated by international networks.

Hypothesis 6 (H6). The relationship between cultural differences and international performance can be mediated by international networks.

\subsection{International Performance and Competitiveness}

Earlier studies of international performance and competitiveness demonstrated a significant correlation between these two factors [61-63]. Carlin [62] used data from 12 manufacturing industries in 14 organizations for economic cooperation and development (OECD) countries and found that international performance has a significant effect on competitiveness. Momaya and Selby [64] also argued that international performance enhances competitiveness. More recently, Dethier [65] found that recent export performance in developing countries provides a basis for the comprehensive mapping of their competitiveness. Finally, Freixanet [66] confirmed that there was a significant correlation between international performance and competitiveness because exporters' main activities are to internationalize, thus connecting international performance with competitiveness. Therefore, this study proposes its final hypothesis based on these studies regarding the relationship between performance and competitiveness.

Hypothesis 7 (H7). International performance has a positive (+) effect on competitiveness.

According to the above theories on network, in order to improve competitiveness, organization-especially SMEs-must establish useful networks with other stakeholders. This can be explained from the perspective of open innovation. For supplementing insufficient resources, SMEs must pursue open innovation by establishing networks. That is to say, with the perspective view of open innovation and the advantages of physical, social, and cultural factors, firms can establish useful networks and improve organizational performance and competitiveness. The conceptual model that explains these theoretical positions and relationships between related variables is as follows. Information management, cultural difference, and proximity act as antecedents of an international network, and international performance and competitiveness function as consequences of the network. In addition, the network acts as a mediating variable. Finally, the experience on open innovation functions as a control variable. (See the Figure 1) 


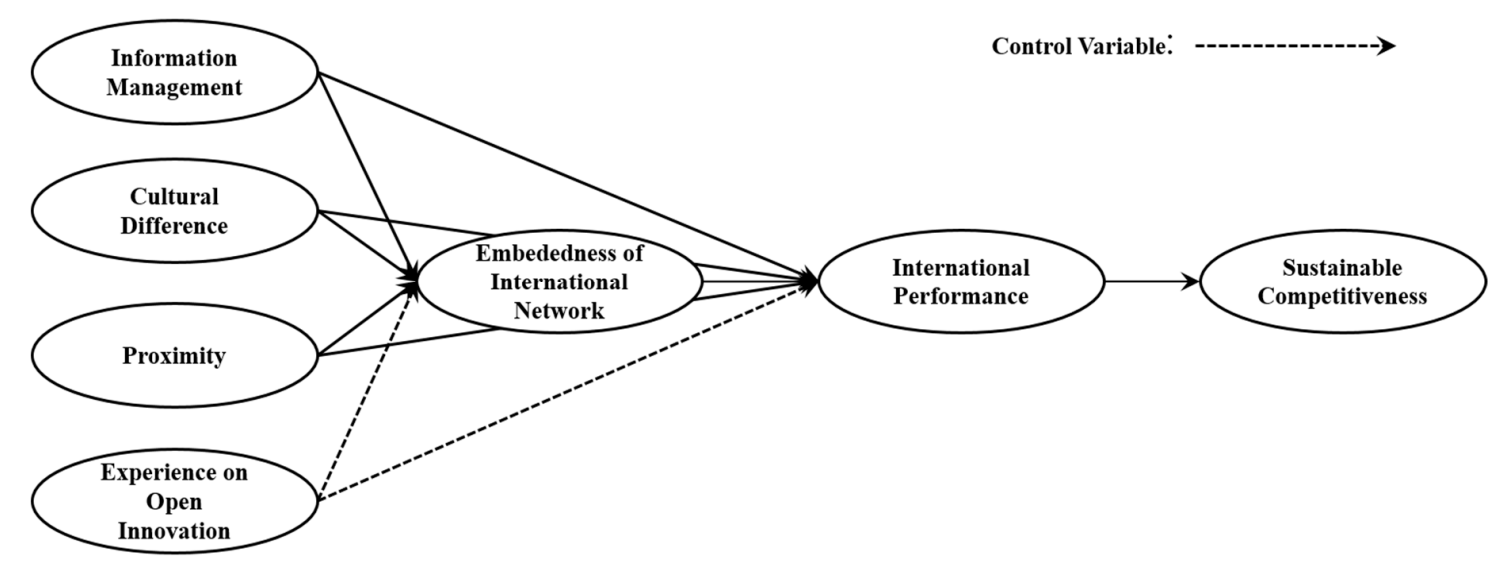

Figure 1. Conceptual Model. Source: authors

\section{Methodology}

\subsection{Sample and Data Collection}

Exporters were located using a variety of database sources, such as the Small \& Medium Business Administration (SMBA) and the Korea International Trade Association (KITA). This study used data from small and medium-sized exporters, which was collected using multiple sources, such as addresses, email, and websites, in order to choose a research sample because there is no formal or official data to identify this sample [67]. The authors first collected a list of small and medium-sized enterprises from the SMBA and identified 1124 small and medium-sized enterprises suitable for this study. This sample was sent to KITA to determine whether the SMEs have export experience, resulting in a sample of 527 eligible exporters. The data provided by KITA was verified by visiting the exporters' websites or homepages, reducing the sample population to 500. Finally, since there is no official database to confirm reliability and validity of the sampling procedure, one month before the beginning the survey, the companies' websites were again checked to confirm their suitability for this study. Accordingly, 500 SMEs were chosen for the final analysis. This study uses convenience sampling-a "statistical method to be able to draw representative data choosing people because of the ease of their volunteering or choosing units because of their availability or easy access. The strong points of this kind of sampling are the availability and the quickness with which data can be gathered. The weak points are the risk that the sample might not represent the population on the whole, and it should be biased by volunteers" [68].

The investigation above indicated that most are manufacturing or technology industry-based firms, thus, an online survey would be a better way to collect data, though an offline survey was also employed to increase the survey response rate [69]. The first 350 offline questionnaires were sent in November 2018, with online questionnaires sent to another 150 exporters after four weeks. A reminder was sent via email asking these firms to participate in our survey. Finally, the CEOs or managing directors were contacted directly for improving the response rate more. Finally, we collected 362 questionnaires (response rate: $72.4 \%$ ). Among the responses, six were eliminated because their responses were incomplete. The final sample had 356 complete questionnaires. Table 1 presents the sample description, that is, key characteristics of the sample such as the respondents' position in the organizations and gender, the number of employees in the firm, and the duration of export activity. 
Table 1. Sample description.

\begin{tabular}{lcc}
\hline \multicolumn{1}{c}{ Variables } & Number & Percentage \\
\hline Gender & 248 & \\
Male & 108 & 69.7 \\
Female & & 30.3 \\
\hline Position & 184 & \\
CEO & 116 & 51.7 \\
Director & 56 & 32.6 \\
Senior Manager & & 15.7 \\
\hline Number of Employees & 234 & \\
1-49 & 63 & 64.9 \\
50-99 & 25 & 17.7 \\
100-149 & 35 & 7.0 \\
150-199 & 2 & 9.8 \\
200-299 & & 0.6 \\
\hline Duration of Export & & \\
Activity & 100 & 28.1 \\
1-3 years & 50 & 14.0 \\
3-5 years & 78 & 21.9 \\
5-7 years & 85 & 23.9 \\
7-9 years & 43 & 12.1 \\
More than 9 years & & \\
\hline
\end{tabular}

\subsection{Variables and Measures}

Information management and cultural difference were measured using four items adapted from Ritter et al. [20], Sharmo and Blomstermo [50], and Julien and Ramangalahy [44]. Physical proximity was assessed using three items adapted from Wilkinson [4] and Ritter et al. [20]. International network embeddedness is proposed as a mediator in the relationships between information management, cultural difference, and proximity, and measured using items adapted from Andersson [54] and Ritter et al. [20]. International performance was measured using four indicators: number of international branches, export sales, number of international markets and international assets based on studies by Bloodgood [70] and Kuivalainen [71]. Competitiveness was measured using items adapted from Cox and Blake [72] and Perez and de Pablos [73]. All items were measured on a five-point Likert-type scale $(1=$ strongly disagree; $5=$ strongly agree). (See the Appendix A)

This study used experience on open innovation as a control variable to investigate empirical relationships more clearly. Experience on open innovation was operationalized as the number of years that exporters have established networks [74]. This variable considers the intensity of international network in relation to competitiveness.

\subsection{Analytical Method and Bias}

At regular intervals such as four weeks, questionnaires were collected in order to minimize common method bias, though it was unfeasible to entirely eliminate the bias because all items on the questionnaire were measured using one survey [75]. Thus, we assessed the likelihood of common method bias by the confirmatory factor analysis (CFA). As a result, there is no statistical significance (i.e., an extremely poor model fit; $\chi^{2}=5747.784(\mathrm{df}=299, p=0.000), \chi^{2} / \mathrm{df}=19.23$, goodness-of-fit-index (GFI) $=0.387$, adjusted goodness-of-fit-index $(\mathrm{AGFI})=0.281$, normed fit index $(\mathrm{NFI})=0.409$, turker-lewis index $(\mathrm{TLI})=0.369$, comparative fit index $(\mathrm{CFI})=0.420$, root mean square residual $(\mathrm{RMR})=0.166$, and root mean square error of approximation $($ RMSEA $)=0.227$ ). Thus, we can argue that our results should not be affected by the bias. Through the t-test, the likelihood of non-response bias was evaluated [76]. The early (within four weeks of the mailing) and late responses (more than four weeks after the mailing) were separated and compared in terms of information management, cultural 
difference, proximity, international network, international performance, and competitiveness. The results indicate no significant difference between the two groups (information management, $p=0.612$; cultural difference, $p=0.465$; proximity, $p=0.177$; international network, $p=0.608$; international performance, $p=0.440$; competitiveness, $p=0.885$ ), and thus, we could argue that there should be no non-response bias in this study.

\section{Analysis and Results}

\subsection{Measurement and Structural Model Results}

The data were analyzed using the structural equation model (SEM) to investigate the relationships among the antecedents of international networks, international competitiveness, and international performance. SEM is one of the most effective methods to measure mediating effects because all relevant paths can be directly verified [77].

Before testing the hypotheses, we analyzed the measurement model made to estimate both the reliability and the validity of constructs. The measurement model was evaluated using CFA consisting of six constructs using the IBM AMOS 21.0 software package (IBM, New York, NY, USA). The CFA results are as follows: $\chi^{2}=909.475$, degrees of freedom $(\mathrm{df})=283, \chi^{2} / \mathrm{df}=3.214 ; \mathrm{RMR}=0.074 ; \mathrm{NFI}=$ 0.906; CFI $=0.931$; TLI $=0.913$; incremental fit index $(\mathrm{IFI})=0.916$; RMSEA $=0.084$ (see Table 2) [78-83] . Based on these values, it is possible to accept the model — that is, the mode fit is suitable to be analyzed.

Table 2. Measurement model results.

\begin{tabular}{|c|c|c|c|c|c|c|c|c|c|}
\hline \multirow{2}{*}{ Scale } & \multirow{2}{*}{ Mean } & \multirow{2}{*}{$\begin{array}{c}\text { Standard } \\
\text { Deviation }\end{array}$} & \multicolumn{7}{|c|}{ Cross-Construct Correlations } \\
\hline & & & (1) & (2) & (3) & (4) & (5) & (6) & (7) \\
\hline (1) & 2.7781 & 1.39362 & 1 & & & & & & \\
\hline (2) & 2.5716 & 1.06965 & $0.176^{* *}$ & 1 & & & & & \\
\hline (3) & 2.7331 & 0.93187 & -0.078 & $-0.288 * *$ & 1 & & & & \\
\hline (4) & 2.7200 & 0.87208 & 0.041 & $0.529 * *$ & $-0.362 * *$ & 1 & & & \\
\hline (5) & 2.8240 & 0.89455 & $0.209 * *$ & $0.548^{* *}$ & $-0.460 * *$ & $0.591 * *$ & 1 & & \\
\hline (6) & 2.5632 & 0.98789 & $0.280^{* *}$ & $0.614^{* *}$ & $-0.237^{* *}$ & $0.460 * *$ & $0.411^{* *}$ & 1 & \\
\hline (7) & 2.5035 & 0.98946 & $0.254^{* *}$ & $0.297 * *$ & $-0.323 * *$ & $0.455^{* *}$ & $0.458^{* *}$ & $0.319 * *$ & 1 \\
\hline \multicolumn{3}{|c|}{ Cronbach's $\alpha$} & & 0.910 & 0.818 & 0.837 & 0.948 & 0.937 & 0.923 \\
\hline \multicolumn{3}{|c|}{ Construct Reliability } & & 0.868 & 0.956 & 0.851 & 0.944 & 0.933 & 0.958 \\
\hline \multicolumn{3}{|l|}{ AVE } & & 0.625 & 0.844 & 0.658 & 0.737 & 0.778 & 0.822 \\
\hline \multicolumn{3}{|c|}{ Goodness-of-fit statistics } & \multicolumn{7}{|c|}{$\begin{array}{l}\chi^{2}=909.475(\mathrm{df}=283), \chi^{2} / \mathrm{df}=3.214, \mathrm{RMR}=0.074, \mathrm{NFI}=0.906, \mathrm{CFI}=0.931, \mathrm{TLI}= \\
0.913, \mathrm{IFI}=0.916, \mathrm{RMSEA}=0.084\end{array}$} \\
\hline
\end{tabular}

* Significant at $p<0.01 .{ }^{*}$ Significant at $p<0.05$. (1) Experience on open innovation; (2) Information Management;
(3) Cultural Difference; (4) Proximity; (5) International Network; (6) Competitiveness; (7) International Performance.

The reliability of all constructs assessed using Cronbach's alpha $(\alpha)$ values returned results ranging from 0.818 to 0.948 , which are acceptable [84]. Moreover, the construct reliabilities of each scale ranged from 0.851 to 0.958 [85]. The values in Table 2 also report the results for the average variance extracted (AVE) values to estimate the convergent validity of constructs. The AVE values of all variables were more than 0.625 , explaining that the measurement model had proper or satisfactory convergent validity [86]. Discriminant validity was assessed using a cross-construct correlation estimate [87] showing satisfactory discriminant validity. Moreover, there are no correlations between constructs of 0.85 or more than, which would indicate poor discriminant validity [88], further confirming that the measurement model has proper or satisfactory discriminant validity.

The structural model in the study indicates that the $\chi^{2}$ value is 985.100 , the $d f$ is 309 , and the $\chi^{2} / \mathrm{df}$ is 3.188 . These results are not statistically and perfectly satisfactory, so other measures should be evaluated. As shown in Table 3, the values of these indices (RMR $=0.074, \mathrm{NFI}=0.914, \mathrm{CFI}=0.936$, TLI $=0.919$, RMSEA $=0.078$, and IFI $=0.937$ ) are within range, indicating a satisfactory model fit. 
Table 3. Standardized structural estimates of the structural model (mediating effect model).

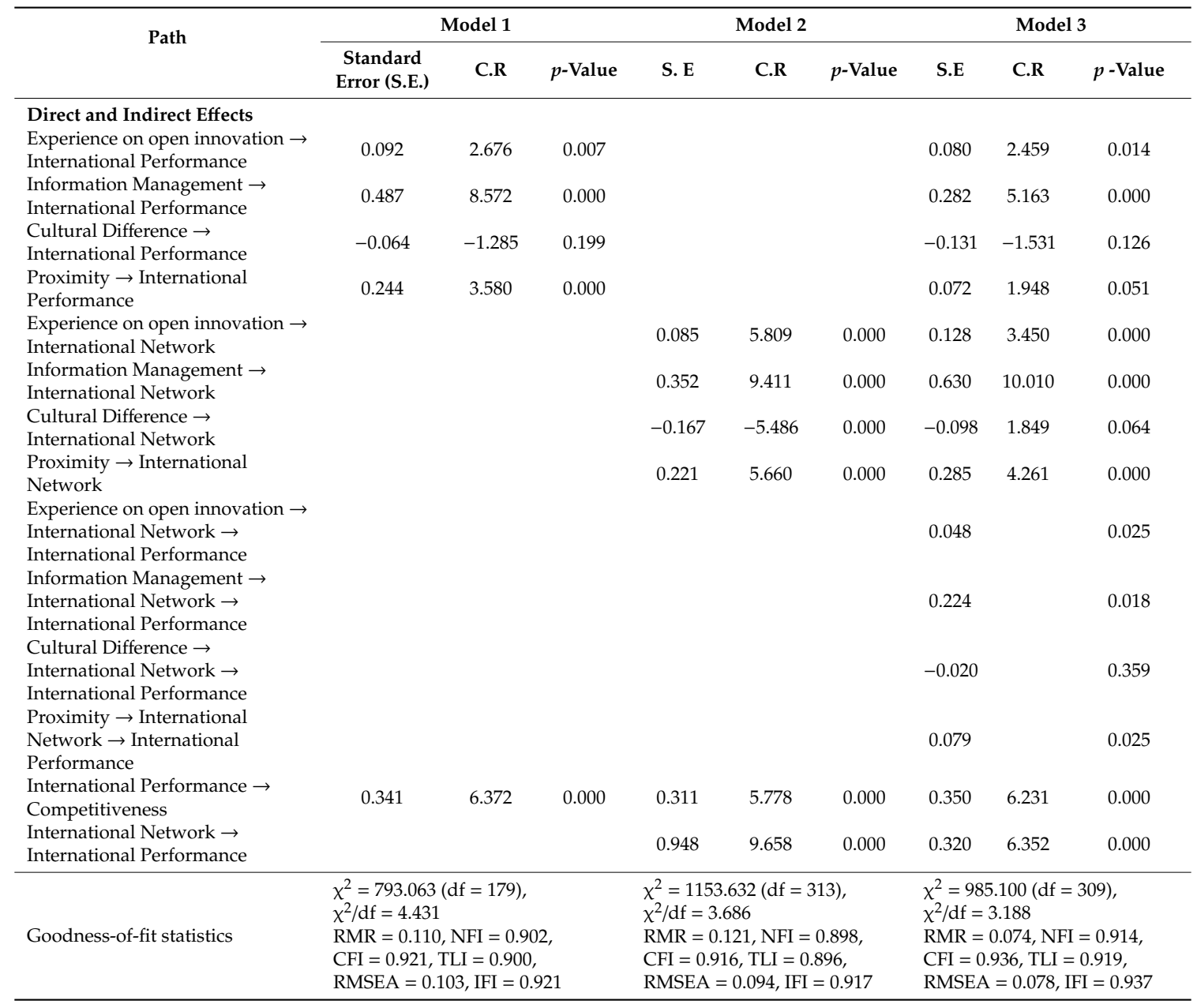

\subsection{Hypotheses Testing}

The hypotheses were tested by investigating disintegration effects. An independent variable has both direct and indirect effects [89]. Table 3 shows the results of the structural model including the direct and indirect effects of all paths.

The hypotheses were assessed using the results for Model 3. Direct effects could predict a significant relationship between information management, cultural difference and proximity, and international network embeddedness. Apart from cultural differences, both information management $(\lambda=0.630$, critical ratio $(C . R)=10.010, p<0.001)$ and proximity $(\lambda=0.285, C . R=4.261, p<0.001)$ had significant positive effects on international network embeddedness, implying that a bigger difference in information management and proximity between exporters and other companies (e.g., importer, distributer, and related expert) make international network embeddedness more difficult. Contrary to expectations, cultural differences did not have a meaningful effect on international networks. SMEs should therefore not consider this factor since they can mitigate this by learning through the Internet or by indirect travel experience and cultural content such as television shows and films [42]. These results, related to information management and proximity, are in line with Rivera's [31] findings and support Hypotheses 1 and 3.

To verify the mediating role of international network embeddedness, this study examined the indirect effect suggested by Baron and Kenny [77] by establishing three models. Model 1 tested the relationships between the independent variables (i.e., information management, cultural difference, and proximity) and the dependent variable (i.e., international performance); Model 2 verified the relationships between the independent variables and the mediating variable (i.e., international network 
embeddedness); and Model 3 investigated the relationships among the independent variables, the mediator, and the dependent variable. Model 3 is a better model fit than Model 2, assuming that the international network embeddedness functions as a mediator. Testing the mediating effects requires an examination of all three models, despite the better fit of Model $3[77,90]$. As shown in Model 1, apart from cultural differences, information management $(\lambda=0.487, C . R=8.572, p<0.001)$ and proximity $(\lambda=0.244, C . R=3.580, p<0.001)$ has significant positive effects on international performance, thus partially satisfying the first requirement of a mediating effect. Model 2 shows the second condition-the relationships between the independent and mediating variables. All independent variables influenced international network embeddedness: information management $(\lambda=0.325, C . R=9.411, p<0.001)$, cultural difference $(\lambda=-0.167, C . R=-5.486, p<0.001)$, and proximity $(\lambda=0.221, C . R=5.660, p<$ $0.001)$. These results satisfy the second condition completely.

Finally, the significance of the indirect effects indicate that international network embeddedness mediated the relationships between information management and proximity and international performance based on Model 3, indicating that embeddedness influences international performance through managing or controlling information $(\lambda=0.224, p=0.018)$ and proximity $(\lambda=0.079, p=$ 0.025). In contrast, international network embeddedness had only a partial mediating effect on the relationship between proximity and international performance. These results imply that CEOs of SMEs must consider establishing, and hence embedding, an international network to improve international performance. These findings partially concur with Ritter et al. [20], Bloodgood [70], and Goldenberg and Levy [39], and support Hypotheses 4 and 6. For hypothesis 7, regarding to the relationship between international performance and competitiveness, international performance is a significant variable affecting sustainable competitiveness $(\lambda=0.350, C . R=6.231, p<0.001)$.

\section{Conclusions}

\subsection{Research Implications}

This study examined why SMEs choose international networks and the role of embedded international networks in improving SMEs' international performance and competitiveness. It focused on the proximity mechanism to account for network formation, giving scholars who are interested in explaining network formation a research direction that is better served by the above mechanism. Additionally, by explaining network formation through three mechanisms (such as reach, richness, and receptivity) and a perspective view of open innovation, previous studies [16,74] might be advanced by this study, as it explains the network formation by connecting it to physical mechanism and an open innovation perspective view.

Furthermore, this study complements existing network theories, especially because it ties closer relationships created by various channels with the proximity mechanism, which is a potentially significant academic implication. This study tested the hypotheses by using SEM to test the relationship between international performance and related variables from the perspective of proximity mechanism, and identified the mediating role of international network embeddedness. While most prior studies [91,92] investigating mediating models considered just three variable groups, such as an independent variable, mediator, and dependent variable, this study considered more variable groups to identify whether international performance as a dependent variable affects competitiveness.

Our findings show that, apart from cultural differences, both information management and proximity could function as antecedents of international network embeddedness. This study considered information management, cultural difference, and proximity simultaneously, while earlier studies $[8,39,93]$ did not consider enough factors for why the international networks of SMEs form. As far as we know, there have been no previous comprehensive studies considering these various factors. By considering enough variables to explain international network issues, this study may make a useful contribution toward a comprehensive conceptual model that can confirm the role of international networks in improving international performance. 


\subsection{Practical Implications}

In terms of forming and using an international network in order to increase international performance, this study provides valuable implications for management teams or managers of SMEs in manufacture or technology industries. The results suggest significant mediating effects of international network embeddedness on improved international performance and competitiveness. There are two primary implications for CEOs and managers looking to penetrate global markets. First, strengthening the ability to collect and analyze useful information on targeted international markets can ensure effective international network embeddedness or ties, improving international performance. Thus, it implies that SMEs need to establish innovative information collecting system and/or departments. The networks that can communicate with other organizations such as importers, distributers, local governments, and so on can help CEOs in SMEs improve international performance. Second, to improve competitiveness, CEOs certainly must consider a significant number of variables to increase international performance. The results show that information management and proximity are meaningful factors for improving both international performance and competitiveness. Leaders should work to strengthen information management and manage proximity, and hence anchor these methods in their organizations. Finally, in spite of their limitations, such as the lack of resources, it is better for SMEs to build up international branches and adopt intelligent technology for overcoming far physical distance.

\subsection{Limitations and Avenues for Future Research}

Even though this study makes several significant contributions to the internationalization literature, it has some limitations. First, the study considers only the proximity mechanism because the authors believe that it is the best mechanism to explain international network formation and embeddedness. However, future studies could consider the other two mechanisms, namely complementary and positional. It would be interesting to see a comparative or a difference analysis according to each mechanism. Second, although various variables were considered in this study, there may be additional significant variables affecting international networks such as entrepreneurial characteristics. Oviatt and McDougall [3] noted that international entrepreneurship can play a crucial role in accelerating internationalization. Therefore, entrepreneurial characteristics, such as international entrepreneurship or global orientation, may act as determinants of international networks, and be evaluated in the future along with the variables used in this study. Third, our independent variable group is composed of information management, cultural difference, and proximity. However, information management was previously considered as a way to complement or solve the problem of physical proximity. For instance, if exporters and importers have a large physical distance between them, they overcome this problem by using information. Consequently, future studies should designate a variable related to information management as a moderator rather than as an independent variable. Similarly, Echols and Tsai [94] argued that networks can function as a moderator to improve performance. Therefore, future research on international networks must account for the network as a moderator rather than as a mediator. Fourth, perceived international performance was designated as a dependent variable in this study. In spite of the fact that perception subjective performance can be significantly correlated with objective performance, it is sure that it is better to take into consideration both subjective and objective performance. Thus, we would like to suggest that it is necessary to consider both objective performance such as actual financial data and subjective performance such as organizational effectiveness in future studies. Furthermore, it is difficult to generalize above findings herein because the research focused on SMEs in South Korea. It would be desirable to see comparative studies between two or more countries to improve the generalizability. Finally, this study did not explore the mediating role of international performance or employ various control variables such as age, size and so on, so future research should be carried out, considering the various control variables. 
Author Contributions: Conceptualization, J.Y. and D.R.; methodology, S.S.; software, J.Y.; validation, D.R. and S.S.; formal analysis, D.R.; investigation, J.Y.; resources, S.S.; data curation, D.R.; writing—original draft preparation, J.Y. and D.R.; writing-review and editing, S.S.; visualization, D.R. and S.S.; supervision, J.Y.; project administration, J.Y.; funding acquisition, J.Y.. All authors have read and agreed to the published version of the manuscript.

Acknowledgments: This work was supported by the 2018 Yeungnam University Research Grant. We are very grateful to In Jun and Daesu Kim for their many helpful comments, and to D.R. (main correspondence) and S.S. (co-correspondence) for their collaboration.

Conflicts of Interest: The authors report no other conflict of interest in this work.

\section{Appendix A}

Table A1. Measurement items.

\begin{tabular}{|c|c|c|}
\hline Variables & Items & Sources \\
\hline Information Management & $\begin{array}{l}\text { - Our organization can collect international market information } \\
\text { effectively. } \\
\text { - Our organization can collect useful information about } \\
\text { successful internationalization. } \\
\text { - Our organization shares and communicates information with } \\
\text { our potential international partners effectively and positively. } \\
\text { - Our organization utilizes useful information about successful } \\
\text { internationalization }\end{array}$ & $\begin{array}{l}\text { Ritter et al. [20], Sharmo and } \\
\text { Blomstermo [50], Julien and } \\
\text { Ramangalahy [44] }\end{array}$ \\
\hline Cultural Difference & $\begin{array}{l}\text { - It is difficult to harmonize with potential international partners. } \\
\text { - It is difficult to work out constructive solutions due to cultural } \\
\text { differences when there is conflict. } \\
\text { - It is difficult to understand potential international partners' } \\
\text { behaviors when they have different cultural backgrounds. } \\
\text { - Our organization is not friendly when dealing with potential } \\
\text { international partners with different cultural backgrounds. }\end{array}$ & $\begin{array}{l}\text { Ritter et al. [20], Sharmo and } \\
\text { Blomstermo [50], Julien and } \\
\text { Ramangalahy [44] }\end{array}$ \\
\hline Proximity & $\begin{array}{l}\text { - Our organization feels that there is a smaller physical distance } \\
\text { between potential international partners and it. } \\
\text { - Our organization feels that there is a smaller psychological } \\
\text { distance between potential international partners and it. } \\
\text { - Our organization thinks that proximity plays an important role } \\
\text { in forming and embedding a network with potential } \\
\text { international partners. }\end{array}$ & $\begin{array}{l}\text { Wilkinson [4], Ritter et al. } \\
\text { [20] }\end{array}$ \\
\hline $\begin{array}{l}\text { International Network } \\
\text { Embeddedness }\end{array}$ & $\begin{array}{l}\text { - Our organization forms strong and close relationships with } \\
\text { potential international partners. } \\
\text { - Our organization has strong and close relationships with } \\
\text { international partners. } \\
\text { - Our organization communicates with international partners } \\
\text { frequently. } \\
\text { - Our organization coordinates activities to form strong and close } \\
\text { relationships with potential international partners effectively } \\
\text { and positively. } \\
\text { - An international network between our organization and } \\
\text { international partners is well embedded. } \\
\text { - Our international partners trust us. }\end{array}$ & $\begin{array}{l}\text { Andersson [54], Ritter et al. } \\
\text { [20] }\end{array}$ \\
\hline International Performance & $\begin{array}{l}\text { - Export sales have been improving. } \\
\text { - The number of international markets has been increasing. } \\
\text { - International assets have been improving. } \\
\text { - The number of international branches has been increasing. }\end{array}$ & $\begin{array}{l}\text { Bloodgood [70], Kuivalainen } \\
\text { [71] }\end{array}$ \\
\hline Competitiveness & $\begin{array}{l}\text { - The overall competitiveness of our organization has been } \\
\text { improving. } \\
\text { - Our organization has higher competitiveness than our } \\
\text { competitors. } \\
\text { - Our organization has higher service quality than our } \\
\text { competitors. } \\
\text { - Service quality and competitiveness have been improving. } \\
\text { - Organizational capabilities have been improving. }\end{array}$ & $\begin{array}{l}\text { Cox and Blake [72], Perez } \\
\text { and de Pablos [73] }\end{array}$ \\
\hline
\end{tabular}

\section{References}

1. Acs, Z.J.; Braunerhjelm, P.; Audretsch, D.B.; Carlsson, B. A knowledge spillover theory of entrepreneurship. Small Bus. Econ. 2009, 32, 15-30. [CrossRef] 
2. Kingsley, G.; Malecki, E.J. Networking for competitiveness. Small Bus. Econ. 2004, 23, 71-84. [CrossRef]

3. Oviatt, B.M.; McDougall, P.P. Defining International entrepreneurship and modelling the speed of internationalization. Entrep. Theory Pract. 2005, 29, 537-553. [CrossRef]

4. Wilkinson, I.F. A history of channels and network thinking in marketing in the twentieth century. Australas. Mark. J. 2001, 9, 23-53. [CrossRef]

5. Monferrer, D.; Blesa, A.; Ripollés, M.; Kuster, I.; Vila, N. Effect of network market orientation on new venture's international performance. Int. J. Bus. Environ. 2013, 5, 268-298. [CrossRef]

6. Egbetokum, A.; Oluwadare, A.J.; Ajao, F.; Jegede, O.O. Innovation systems research: An agenda for developing countries. J. Open Innov. Technol. Mark. Complex. 2017, 3, 25. [CrossRef]

7. Erramilli, M.K.; D'Souza, D.E. Venturing into foreign markets: The case of the small service firm. Entrep. Theory Pract. 1993, 17, 29-41. [CrossRef]

8. Riddle, L.A.; Gillespie, K. Information sources for new ventures in the Turkish clothing export industry. Small Bus. Econ. 2003, 20, 105-120. [CrossRef]

9. Yli-Renko, H.; Autio, E. The network embeddedness of new, technology-based firms: Developing a systemic evolution model. Small Bus. Econ. 1998, 11, 253-267. [CrossRef]

10. Kiss, A.N.; Danis, W.M. Social networks and speed of new venture internationalization during institutional transition: A conceptual model. J. Int. Entrep. 2010, 8, 273-287. [CrossRef]

11. McDougall, P.P.; Shane, S.; Oviatt, B.M. Explaining the formation of international new ventures the limits of theories from international-business research. J. Bus. Ventur. 1994, 9, 469-487. [CrossRef]

12. Coviello, N.E. The network dynamics of international new ventures. J. Int. Bus. Stud. 2006, 37, 713-731. [CrossRef]

13. Hafner-Burton, E.M.; Kahler, M.; Montgomery, A.H. Network analysis for international relations. Int. Organ. 2009, 63, 559-592. [CrossRef]

14. Kim, C.-B.; Ronto, S.E. Business performance, process innovation and business partnership in the global supply chain of Korean manufacturers. J. Korea Trade 2010, 14, 61-83.

15. McPherson, M.; Smith-Lovin, L.; Brashears, M. Social isolation in America: Changes in core discussion networks over two decades. Am. Sociol. Rev. 2006, 71, 353-375. [CrossRef]

16. Gulati, R.; Lavie, D.; Madhavan, R. How do networks matter? The performance effects of interorganizational networks. Res. Organ. Behav. 2011, 31, 207-224. [CrossRef]

17. Camisón, C.; Villar-López, A. Effect of SMEs' international experience on foreign intensity and economic performance: The mediating role of internationally exploitable assets and competitive strategy. J. Small Bus. Manag. 2010, 48, 116-151. [CrossRef]

18. Uzzi, B. Social structure and competition in inter-firm networks: The paradox of embeddedness. Adm. Sci. Quart. 1997, 42, 35-67. [CrossRef]

19. Lee, I.W. Determinants of network in cooperation between local governance: The relationships between determinants of network of local governance and centricity. Korean J. Local Gov. Stud. 2013, 17, 117-139.

20. Ritter, T.; Wilkinson, I.F.; Johnston, W.J. Measuring network competence: Some international evidence. J. Bus. Ind. Mark. 2002, 17, 119-138. [CrossRef]

21. Lee, Y.M.; Lee, I.W.; Feiock, R. Internationalization collaboration networks in economic development policy: An exponential random graph model analysis. Policy Stud. J. 2012, 40, 547-573. [CrossRef]

22. Choi, Y.; Cho, D.-S.; Kwon, K.-H. Subsidiary's external networkability as a source of competitive advantage. J. Korea Trade 2007, 11, 107-139.

23. Feiock, R.C.; Scholz, J.T. Self-Organizing Federalism: Collaborative Mechanisms to Mitigate Institutional Collective Action Dilemmas; Cambridge University Press: Cambridge, UK, 2010.

24. Fritsch, M.; Schroeter, A. Why does the effect of new business formation differ across regions? Small Bus. Econ. 2011, 36, 383-400. [CrossRef]

25. Hsueh, J.T.; Lin, N.P.; Li, H.C. The effects of network embeddedness on service innovation performance. Serv. Ind. J. 2010, 30, 1723-1736. [CrossRef]

26. Danese, P.; Romano, P.; Formentini, M. The impact of supply chain integration on responsiveness: The moderating effect of using an international supplier network. Transp. Res. Part E Logist. Transp. Rev. 2013, 49, 125-140. [CrossRef]

27. Coleman, J.S. Social capital in the creation of human capital. Am. J. Sociol. 1988, 94, S95-S120. [CrossRef] 
28. Cooke, P.A. Ground-Up “Quaternary" innovation strategy for South Korea using entrepreneurial ecosystem platforms. J. Open Innov. Technol. Mark. Complex. 2017, 3, 10. [CrossRef]

29. Gulati, R. Network location and learning: The influence of network resources and firm capabilities on alliance formation. Strateg. Manag. J. 1999, 30, 397-420. [CrossRef]

30. Kim, J.H. The influence of relationship strength among business partners on performance in international strategic alliances. Korean J. Econ. Manag. 2004, 33, 273-296.

31. Rivera, M.T.; Soderstrom, S.B.; Uzzi, B. Dynamics of dyads in social networks: Assortative, relational and proximity mechanisms. Annu. Rev. Sociol. 2010, 36, 91-115. [CrossRef]

32. Fleming, L.; King, C., III; Juda, A.I. Small worlds and regional innovation. Organ. Sci. 2007, 18, 938-954. [CrossRef]

33. Hsu, M.; Bhatt, M.; Adolphs, P.; Trane, D.; Camerer, C.F. Neural systems responding to degrees of uncertainty in human decision-making. Science 2005, 310, 1680-1683. [CrossRef] [PubMed]

34. Gulati, R.; Nohria, N.; Zaheer, A. Strategic networks. Strateg. Manag. J. 2000, 21, 203-215. [CrossRef]

35. Park, H.S. Technology convergence, open innovation, and dynamic economy. J. Open Innov. Technol. Mark. Complex. 2017, 3, 24. [CrossRef]

36. Schilling, M.A.; Phelps, C.C. Inter firm collaboration networks: The impact of large-scale network structure on firm innovation. Manag. Sci. 2007, 53, 1113-1126. [CrossRef]

37. Uzzi, B.; Spiro, J. Collaboration and creativity: The small world problem. Am. J. Sociol. 2005, 111, 447-504. [CrossRef]

38. Watts, D.J. Network, dynamics, and the small-world phenomenon. Am. J. Sociol. 1999, 105, $493-527$. [CrossRef]

39. Goldenberg, J.; Levy, M. Distance is not dead: Social interaction and geographical distance in the internet era. Comput. Sci. 2009, 1, 1-22.

40. Moon, H.J.; Kim, P.; Bea, I.G. Determinants of supply chain partnership and performance. E Bus. Res. 2009, 10, 363-364.

41. Park, D.G.; Hang, S.W.; Jo, C.H. Information systems and its performance in container yard operation companies. Int. Commer. Manag. 2009, 24, 106-124.

42. Mok, D.; Wellman, B.; Carrasco, J. Does distance matter in the age of the Internet? Urban Stud. 2010, 47, 2747-2783. [CrossRef]

43. Li, H.; Atuahene-Gima, K. Product innovation strategy and the performance of new technology ventures in China. Acad. Manag. J. 2001, 44, 1123-1134.

44. Julien, P.A.; Ramangalahy, C. Competitive strategy and performance of exporting SMEs: An empirical investigation of the impact of their export information search and competencies. Entrep. Theory Pract. 2003, 27, 227-245. [CrossRef]

45. Child, J.; Hsieh, L.H. Decision mode, information and network attachment in the internationalization of SMEs: A configurational and contingency analysis. J. World Bus. 2014, 49, 598-610. [CrossRef]

46. Thomas, A.S.; Mueller, S.L. A case for comparative entrepreneurship: Assessing the relevance of culture. J. Int. Bus. Stud. 2000, 31, 287-301. [CrossRef]

47. Stepanyan, K.; Mather, R.; Dalrymple, R. Culture, role and group work: A social network analysis perspective on an online collaborative course. Br. J. Educ. Technol. 2014, 45, 676-693. [CrossRef]

48. Wang, C.L.; Altinay, L. Social embeddedness, entrepreneurial orientation and firm growth in ethnic minority small businesses in the UK. Int. Small Bus. J. 2010, 30, 3-23. [CrossRef]

49. Jo, Y.G. Difference of culture between business partners in international joint investment: The effect of governing structures on performance. J. Int. Manag. 2004, 8, 83-85.

50. Sharma, D.D.; Blomstermo, A. The internationalization process of born globals: A network view. Int. Bus. Rev. 2003, 12, 739-753. [CrossRef]

51. Koh, Y.-K.; Lim, J.-S.; Lee, H.-Y. A model for the mechanism of container ports' cooperation networks in Northeast Asia. J. Korea Trade 2007, 11, 115-136.

52. Musteen, M.; Francis, J.; Datta, D.K. The influence of international networks on internationalization speed and performance: A study of Czech SMEs. J. World Bus. 2010, 45, 197-205. [CrossRef]

53. Sepulveda, F.; Gabrielsson, M. Network development and firm growth: A resource-based study of B2B Born Globals. Ind. Mark. Manag. 2013, 42, 792-804. [CrossRef] 
54. Andersson, U.; Forsgren, M.; Holm, U. The strategic impact of external networks: Subsidiary performance and competence development in the multinational corporation. Strateg. Manag. J. 2002, 23, 979-996. [CrossRef]

55. Kalwani, M.U.; Narayandas, N. Long-term manufacturer-supplier relationships: Do they pay off for supplier firms? J. Mark. 1995, 59, 1-16. [CrossRef]

56. Kotler, P.; Armstrong, G. Principles of Marketing; Prentice-Hall: Englewood Cliffs, NJ, USA, 1991.

57. Schijndel, L.V. TCKF-Connect: A Cross-Disciplinary Conceptual Framework to Investigate Internationalization within the Context of Entrepreneurial Ecosystems. J. Open Innov. Technol. Mark. Complex. 2019, 5, 28. [CrossRef]

58. Yoon, J.; Kim, D. Empirical relationships among technological characteristics, global Orientation, and internationalisation of South Korean new ventures. Sustainability 2016, 8, 1254. [CrossRef]

59. Kim, D.S.; Lee, D.S. Impacts of metacognition on innovative behaviors: Focus on the mediating effects of entrepreneurship. J. Open Innov. Technol. Soc. Complex. 2018, 4, 18. [CrossRef]

60. Winch, G. Strategic business and network positioning for internationalization. Serv. Ind. J. 2014, 34, 715-728. [CrossRef]

61. Binder, P. Impacts of network relationships on absorptive capacity in the context of innovation. Serv. Ind. J. 2018, 30, 1-29. [CrossRef]

62. Carlin, W.; Glyn, A.; Van Reenen, J. Export market performance of OECD Countries: An empirical examination of the role of cost competitiveness. Econ. J. 2001, 111, 128-162. [CrossRef]

63. Lall, S. Competitiveness indices and developing countries: An economic evaluation of the global competitiveness report. World Dev. 2001, 29, 1501-1525. [CrossRef]

64. Momaya, K.; Selby, K. International competitiveness of the Canadian construction industry: A comparison with Japan and the United States. Can. J. Civil Eng. 1998, 25, 640-652. [CrossRef]

65. Dethier, J.J.; Hirn, M.; Straub, S. Explaining enterprise performance in developing countries with business climate survey data. World Bank Res. Obs. 2010, 26, 258-309. [CrossRef]

66. Freixanet, J. Export promotion programs: Their impact on companies' internationalization performance and competitiveness. Int. Bus. Rev. 2012, 21, 1065-1086. [CrossRef]

67. Nummela, N.; Saarenketo, S.; Puumalainen, K. Global mind set-A prerequisite for successful internationalization? Can. J. Adm. Sci. 2004, 21, 51-64. [CrossRef]

68. Brodaty, H.; Mothakunnel, A.; de Vel-Palumbo, M.; Ames, D.; Ellis, K.A.; Reppermund, S.; Sachdev, P.S. Influence of population versus convenience sampling on sample characteristics in studies of cognitive aging. Ann. Epidemiol. 2014, 24, 63-71. [CrossRef]

69. Kaplowitz, M.C.; Hadlock, T.D.; Levine, R. A comparison of web and mail survey response rates. Public Opin. Quart. 2004, 68, 94-101. [CrossRef]

70. Bloodgood, J.M. Venture adolescence: Internationalization and performance implications of maturation. Int. J. Entrep. Behav. Res. 2006, 12, 67-85. [CrossRef]

71. Kuivalainen, O.; Sundqvist, S.; Servais, P. Firms' degree of born-globalness, international entrepreneurial orientation and export performance. J. World Bus. 2007, 42, 253-267. [CrossRef]

72. Cox, T.; Blake, S. Managing cultural diversity: Implications for organizational competitiveness. Executive 1991, 5, 45-56. [CrossRef]

73. Perez, J.R.; de Pablos, P.O. Knowledge management and organizational competitiveness: A framework for human capital analysis. J. Knowl. Manag. 2003, 7, 82-91. [CrossRef]

74. Lee, S.; Park, G.; Yoon, B.; Park, J. Open innovation in SMEs-An intermediated network model. Res. Policy 2010, 39, 290-300. [CrossRef]

75. Podsakoff, P.M.; Organ, D.W. Self-reports in organizational research: Problems and prospects. J. Manag. 1986, 12, 531-544. [CrossRef]

76. Armstrong, J.S.; Overton, T.S. Estimating nonresponse bias in mail surveys. J. Mark. Res. 1977, 14, $396-402$. [CrossRef]

77. Baron, R.M.; Kenny, D.A. The moderator-mediator variable distinction in social psychological research: Conceptual, strategic, and statistical considerations. J. Personal. Soc. Psychol. 1986, 51, 1173-1182. [CrossRef]

78. Bagozzi, R.P.; Baumgartner, H. The evaluation of structural equation models and hypothesis testing. In Principles of Marketing Research; Bagozzi, R., Ed.; Blackwell: Cambridge, MA, USA, 1994; pp. 386-422. 
79. Jöreskog, K.G.; Sörbom, D. LISREL V: Analysis of Linear Structural Relationships by Maximum Likelihood and Least Squares Methods; University of Uppsala: Uppsala, Sweden, 1981.

80. Hu, L.; Bentler, P.M. Cutoff criteria for fit indexes in covariance structure analysis: Conventional criteria versus new alternatives. Struct. Equ. Model. A Multidiscip. J. 1999, 6, 1-55. [CrossRef]

81. Bentler, P.M.; Bonett, D.C. Significance tests and goodness of fit in the analysis of covariance structures. Psychol. Bull. 1980, 88, 588-606. [CrossRef]

82. Bentler, P.M. Comparative fit indexes in structural models. Psychol. Bull. 1990, 107, 238-246. [CrossRef]

83. Bollen, K.A. Structural Equations with Latent Variables; Wiley-Interscience: New York, NY, USA, 1989.

84. Nunnally, J.C. Psychometric Theory, 2nd ed.; McGraw-Hill: New York, NY, USA, 1978.

85. Fornell, C.; Larcker, D.F. Evaluating structural equation models with unobservable and measurement error. J. Mark. Res. 1981, 18, 39-50. [CrossRef]

86. Bagozzi, R.P.; Yi, Y. On the evaluation of structural equation models. J. Acad. Mark. Sci. 1988, 16, 74-94. [CrossRef]

87. Anderson, J.C.; Gerbing, D.W. Structural equation modelling in practice: A review and recommended two-step approach. Psychol. Bull. 1988, 103, 411-423. [CrossRef]

88. Brown, T.A. Confirmatory Factor Analysis for Applied Research; Guilford: New York, NY, USA, 2006.

89. Tabachnick, B.G.; Fidell, L.S. Using Multivariate Statistics; Harper Collins: New York, NY, USA, 1996.

90. James, L.R.; Brett, J.M. Mediators, moderators, and tests for mediation. J. Appl. Psychol. 1984, 69, 307. [CrossRef]

91. Bontis, N.; Booker, L.D.; Serenko, A. The mediating effect of organizational reputation on customer loyalty and service recommendation in the banking industry. Manag. Decis. 2007, 45, 1426-1445. [CrossRef]

92. Stolle, D.; Soroka, S.; Johnston, R. When does diversity erode trust? Neighborhood diversity, interpersonal trust and the mediating effect of social interactions. Political Stud. 2008, 56, 57-75. [CrossRef]

93. Keeble, D.; Lawson, C.; Moore, B.; Wilkinson, F. Collective learning processes, networking and 'institutional thickness' in the Cambridge region. Reg. Stud. 1999, 33, 319-332. [CrossRef]

94. Echols, A.; Tsai, W. Niche and performance: The moderating role of network embeddedness. Strateg. Manag. J. 2005, 26, 219-238. [CrossRef] 